\title{
m-PAI as a Mobile Learning Media for Islamic Religious Education Courses at Universitas Negeri Jakarta
}

\author{
Muhammad Yusro $^{1 *}$, Andy Hadiyanto ${ }^{1}$, Marhamah Syarief ${ }^{2}$, Raihan Rasyidi $^{2}$
}

${ }^{1}$ Universitas Negeri Jakarta, Indonesia

${ }^{2}$ Universitas Islam Jakarta, Indonesia

*Corresponding author. Email: myusro@unj.ac.id

\begin{abstract}
Nowadays, in the digital era, many products of technology about mobile learning have been launched. Mobile learning applications are designed for practice-based learning or visual learning. Lectures are also often equipped with a recorded video to support students' understanding of materials like Islamic Religious Education (Pendidikan Agama Islam/PAI). This study aimed to develop mobile learning for PAI and to assess its feasibility at Universitas Negeri Jakarta. This study applied the research and development method by undertaking procedures in the mobile learning development model in the Analysis, Design, Development, Implementation, and Evaluation (ADDIE) model. Android-based mobile learning for the PAI subject in this study is called m-PAI. The m-PAI application uses the Android Studio 4.0.1 software, which can be accessed and operated in the android-based smartphone with the specification of Android 5.0 Lollipop and 3G/4G connection. This m-PAI application relates to the dashboard system web for an editor to update some contents such as semester lesson plans (RPS), teaching materials, mid-test, and final test. The feasibility test for using mPAI by users shows that $90.26 \%$ of lecturers and $84.28 \%$ of students acceptance rate thus justify the use of mPAI
\end{abstract}

Keywords: ADDIE, android, Islamic religious education, mobile learning, $m-P A I$

\section{INTRODUCTION}

The Islamic religious education course (hereinafter referred to as Pendidikan Agama Islam or PAI) is one of the general subjects that must be taken by students in public universities [1]. This theoretical course is to direct students to become people of faith, have a good personality, and can apply Islamic moral values in all aspects of life.

The PAI curriculum which is currently in use is the 2013 curriculum conceptually based on the several competencies to be achieved with a scientific processbased learning approach (scientific approach) by enabling students (student-centered) to build knowledge (epistemological approaches) that are more activityoriented (activity-based), and not material (content base) [2].
Learning PAI in public universities has 2 (two) or 3 (three) semester credit units to streamline the mission and objectives. This PAI design makes it easier for students to understand learning materials properly, including materials, methods, media, and learning construction is needed [3]. The function of learning media is important in improving the quality of teaching because the presence of the media not only helps teachers in delivering teaching materials but also provides added value to learning activities. The definition of learning media is all forms of physical communication tools that can be used to convey information from sources to students, which aim to stimulate them to take part in learning activities.

Various research related to the development of information technology-based learning media has been carried out by researchers [4][5]. The products of this research are generally in the form of mobile learning as 
media for all levels of education units in schools and colleges, many of which are aimed at non-formal education [6]. Especially for universities, some application products of mobile learning are more aimed at practicum courses or those that require visualization of technical skills, for example, personal computer assembly, basic programming, use of drawing equipment, use of electronic measuring instruments, and so on [7]. On the other hand, many theoretical courses require enrichment and reinforcement of the material using various video examples to provide an in-depth understanding of the teaching material. As one of the academic courses, PAI needs to continue making learning media innovations by utilizing information technology.

Currently, there has been an Android mobile learning application for Islamic learning in the Play Store, and various studies have also been found that have developed Islamic learning mobile applications. It is just that the application of mobile learning in the Play Store dedicated to Islamic religious education in higher education has so far not been completely available. Likewise, research related to the development of mobile learning applications for Islamic religious education courses for universities is very limited. From the current literature search, what has been done is the development of learning media for Islamic religious education for the secondary school level so that the development of the mobile PAI learning media for higher education is an epistemological novelty. This study is aimed at developing mobile learning media for Islamic religious education and assessing its use at Universitas Negeri Jakarta.

\section{RESEARCH METHOD}

The method used in this research was research and development ( $\mathrm{R} \& \mathrm{D})$. This research method produces certain products, followed by testing the effectiveness of the products that have been made [8]. The product that was developed in this study was a learning media mobile for Islamic religious education courses. The media product mobile learning is hereinafter referred to as m-PAI.

The model development of instructional media used a model of ADDIE that consists of five stages: Analysis, Design, Development, Implementation, and Evaluation [9][10]. This model was chosen because the ADDIE model has clear relevance for learning development on a small scale (including using Android applications). The ADDIE model is a simple framework that is useful for designing learning, where the process can be applied in various settings because of its general structure [11]. The developing concept of the mobile learning media model using ADDIE is presented in Figure 1.

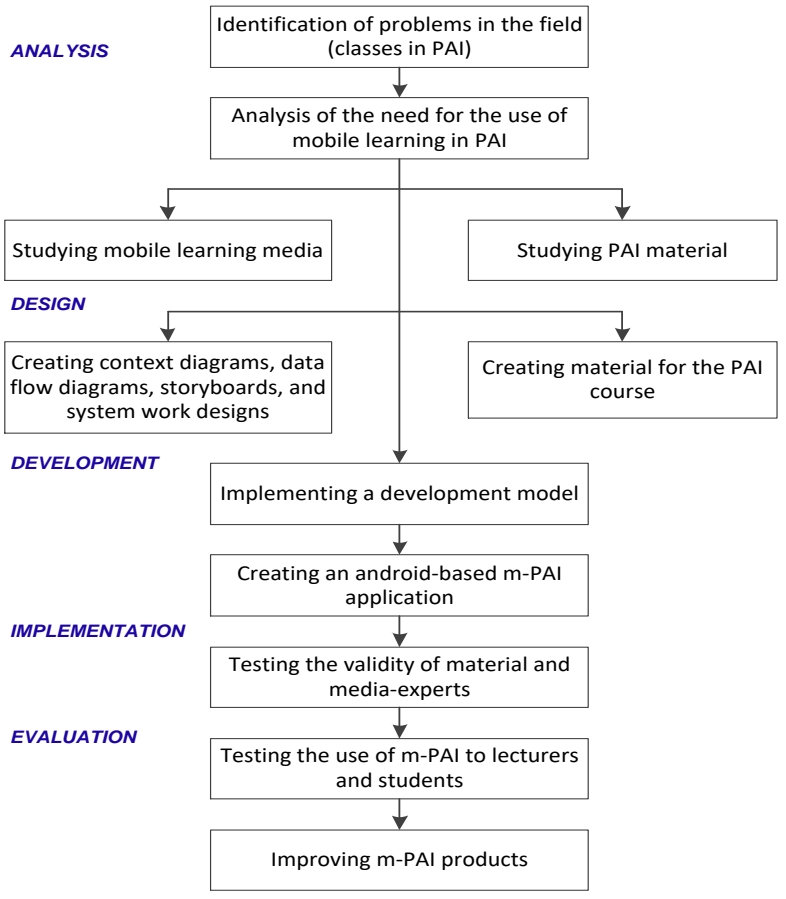

Figure. 1. ADDIE model for m-PAI

The characteristics of the model developed in this study are a) utilizing smartphones Android, which is generally owned by most students and lecturers so that it can be accessed anywhere and anytime; b) integrating the application mobile Android on the user and a web dashboard on the admin (lecturers), so that the material/ content in the Android app can be updated at any time if required by the lecturer of the course; c) containing the PAI semester learning plan, teaching materials, training teaching materials, assignments, learning videos and various learning support features such as al-Qur'an, hadith, e-books, prayer collections, prayer schedule information, qibla direction, and discussions that can be viewed at any time via an Android smartphone that is connected to the internet network.

\section{RESULT AND DISCUSSION}

Analysis stage m-PAI was conducted by interviewing lecturers who taught PAI courses using a zoom meeting platform and distributing online questionnaires using a google form to students of the Universitas Negeri Jakarta (UNJ). The purpose of this need analysis was to determine the extent to which user needs, in this case, PAI UNJ students and lecturers, in relation to the use of mobile learning PAI.

From the results of interviews with PAI lecturers, obtained information was on the content requirements, formulas, and development of existing PAI courses. According to the informant, it is hoped that the content of learning PAI courses that have been arranged according to the curriculum can increase religious knowledge, faith, and devotion and are functional applicative. The PAI course is expected to be able to 
direct achievement and appreciation to student work, answer student needs and draw closer relationships between lecturers and students. Learning strategies for PAI courses are expected to be contextual, with a combination strategy of CTL, problem-solving and inquiry, and multiplying dialogue. The PAI material strategy is expected to be based on the needs of students who have many references and are concrete that religion can answer all human needs. Strategy to use technology needs to be done so that students are interested in studying religion.

The results of the analysis of the needs for the use of mobile learning in PAI were also conducted on student respondents at the UNJ. From the Google Form, which had been distributed for 2 (two) weeks, feedback was obtained from 272 respondents. Respondents came from 6 (six) faculties at UNJ, male and female respondents in this study were almost equal, but from the point of view of education level, there was more undergraduate (bachelor's degree) than those of diploma (associate degree). The characteristics of respondents can be seen in Table 1.

Table 1. Characteristics of student respondents

\begin{tabular}{|l|l|l|}
\hline Characteristics & Number & Percentage (\%) \\
\hline Faculty & & \\
\hline Engineering & 70 & 25.74 \\
\hline Social sciences & 21 & 7.72 \\
\hline Languages and Arts & 39 & 14.33 \\
\hline Economics & 15 & 5.52 \\
\hline Education & 24 & 8.82 \\
\hline Sports science & 103 & 37.87 \\
\hline & & \\
\hline Gender & & \\
\hline Male & 140 & 51.47 \\
\hline Female & 132 & 48.53 \\
\hline & & \\
\hline Education level & & \\
\hline Diploma & 48 & 17.65 \\
\hline Undergraduate & 224 & 82.35 \\
\hline
\end{tabular}

Respondent's response to the quality of Islamic studies/education learning in PAI course describes $84.56 \%$ as good. $80.15 \%$ of PAI lecturers have carried out learning professionally, but only $58.09 \%$ stated that the PAI material being taught had met the needs. Respondent's responses regarding PAI learning media showed that the majority $(94.49 \%)$ believe that PAI courses can be taught through mobile learning Androidbased. As many as $75.74 \%$ of respondents have encountered the Android application for Islamic studies/ education material, but only $23.9 \%$ have used it by installing and using it. This is a challenge in developing attractive mobile learning according to user needs so that it can be utilized optimally.

Some of the input given by students in developing mobile learning PAI courses based on the expected PAI material, namely: tauhid; fiqh; akidah; akhlaq; pillars of faith and Islam; application of Islam in daily life; obligations of a Muslim; rules, and prohibitions; hadith; Al-Qur'an; Islamic modernism and radicalism; history of Islamic culture; and current/contemporary Islamic issues. Some of the input given by students in the development of mobile learning in Islamic education courses based on the expected feature needs, namely: prayer schedules; morning and evening dzikir readings; worship reminders; display of material and exercises; mid-final exam; display of material each subject; recitation of $\mathrm{Al}$ Qur'an; Hadith references and books/books; lectures and quotes; a feature search; Islamic calendar; a question and answer feature with lecturers; displays with attractive colors; the main menu display; guides; material objectives; videos and quizzes; videos worship practice tutorials; google classroom; power-point and PAI materials; user-profiles and Qibla direction.

The stage of creating the design of m-PAI includes determining the PAI subject matter, context diagrams, storyboards, and work design of the application system. Based on the 2020 semester lesson plan (RPS) for the Islamic religious education (PAI) for the diploma and undergraduate levels, the PAI course material that needs to be taught to students is obtained, as shown in Table 2 .

The context diagram illustrates the scope of the system related to external entities acting as a user. In this study, external entities include lecturers and students where students are users while lecturers' areas users well as evaluators or student companions in virtual lectures. The context diagram is depicted in Figure 2.

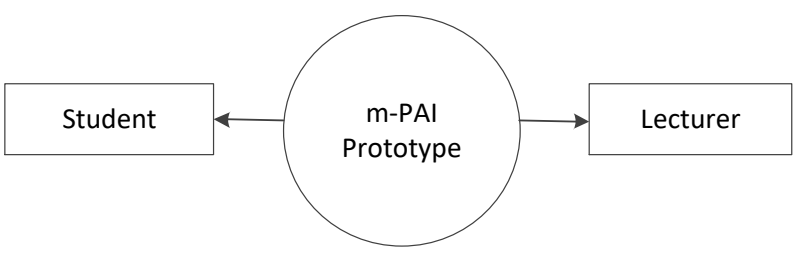

Figure. 2. m-PAI context diagram

The storyboard is a visualization of the idea of the application to be built so that it can provide an overview of the m-PAI application. Development of a system work plan mobile is directed at (a) development of a web dashboard which is a web-based mobile service application on the server-side, and (b) development of a mobile client, which is a mobile application on the client-side that can access web dashboard services. 
Table 2. PAI material/curriculum

\begin{tabular}{|c|c|c|c|}
\hline No & $\begin{array}{l}\text { Undergraduate } \\
\text { Level }\end{array}$ & No & Diploma Level \\
\hline 1 & $\begin{array}{l}\text { The human concept } \\
\text { as God beings }\end{array}$ & 1 & $\begin{array}{l}\text { The human concept } \\
\text { as God beings }\end{array}$ \\
\hline 2 & $\begin{array}{l}\text { The role of religion } \\
\text { in human life }\end{array}$ & 2 & $\begin{array}{l}\text { The role of religion in } \\
\text { human life }\end{array}$ \\
\hline 3 & $\begin{array}{l}\text { Al Qur'an as the } \\
\text { main source of } \\
\text { Islamic law }\end{array}$ & 3 & $\begin{array}{l}\text { Al Qur'an as the } \\
\text { main source of } \\
\text { Islamic law }\end{array}$ \\
\hline 4 & $\begin{array}{l}\text { Sunnah as a source } \\
\text { of Islamic law }\end{array}$ & 4 & $\begin{array}{l}\text { Sunnah as a source } \\
\text { of Islamic law }\end{array}$ \\
\hline 5 & $\begin{array}{l}\text { ljtihad as a source of } \\
\text { Islamic law }\end{array}$ & 5 & $\begin{array}{l}\text { ljtihad as a source of } \\
\text { Islamic law }\end{array}$ \\
\hline 6 & $\begin{array}{l}\text { Concepts and roles } \\
\text { of Islamic morals }\end{array}$ & 6 & $\begin{array}{l}\text { Concepts and roles } \\
\text { of Islamic morals }\end{array}$ \\
\hline 7 & $\begin{array}{l}\text { Concept of science } \\
\text { and technology in } \\
\text { Islam }\end{array}$ & 7 & $\begin{array}{l}\text { Concepts of } \\
\text { harmony and } \\
\text { tolerance in Islam }\end{array}$ \\
\hline 8 & $\begin{array}{l}\text { Work ethics as a } \\
\text { virtuous charity }\end{array}$ & 8 & $\begin{array}{l}\text { Concepts of Islamic } \\
\text { civilization }\end{array}$ \\
\hline 9 & $\begin{array}{l}\text { Concepts of Islamic } \\
\text { family development }\end{array}$ & 9 & $\begin{array}{l}\text { Concept of science } \\
\text { and technology in } \\
\text { Islam }\end{array}$ \\
\hline 10 & $\begin{array}{l}\text { Implementation of } \\
\text { Islamic teachings in } \\
\text { multicultural } \\
\text { societies }\end{array}$ & 10 & $\begin{array}{l}\text { Work ethics as a } \\
\text { virtuous charity }\end{array}$ \\
\hline 11 & $\begin{array}{l}\text { Islamic concepts of } \\
\text { state and } \\
\text { government }\end{array}$ & 11 & $\begin{array}{l}\text { The urgency of soft } \\
\text { skills in work }\end{array}$ \\
\hline 12 & $\begin{array}{l}\text { Islamic concepts of } \\
\text { the environment }\end{array}$ & 12 & $\begin{array}{l}\text { Concepts of Islamic } \\
\text { family development }\end{array}$ \\
\hline 13 & $\begin{array}{l}\text { Concept of hijrah, } \\
\text { jihad, radicalism, } \\
\text { and Islamic } \\
\text { moderation }\end{array}$ & 13 & $\begin{array}{l}\text { Concept of Islamic } \\
\text { leadership }\end{array}$ \\
\hline 14 & $\begin{array}{l}\text { The role of religion } \\
\text { in dealing with } \\
\text { contemporary issues }\end{array}$ & 14 & $\begin{array}{l}\text { The role of religion in } \\
\text { dealing with } \\
\text { contemporary issues }\end{array}$ \\
\hline
\end{tabular}

The development stage of m-PAI is creating an android-based m-PAI application. Android-based mPAI products can be operated on the minimum specifications of Android Lollipop and 3G/4G internet connection. The software used in making this media has the following specifications: Android Studio 4.0.1 to create applications mobile, and Microsoft Visual Code as an editor to create web applications. The hardware used to make the m-PAI application is a personal computer or laptop computer with Intel Processor i5, RAM 8GB, and hard drive 128GB (SSD) specifications.

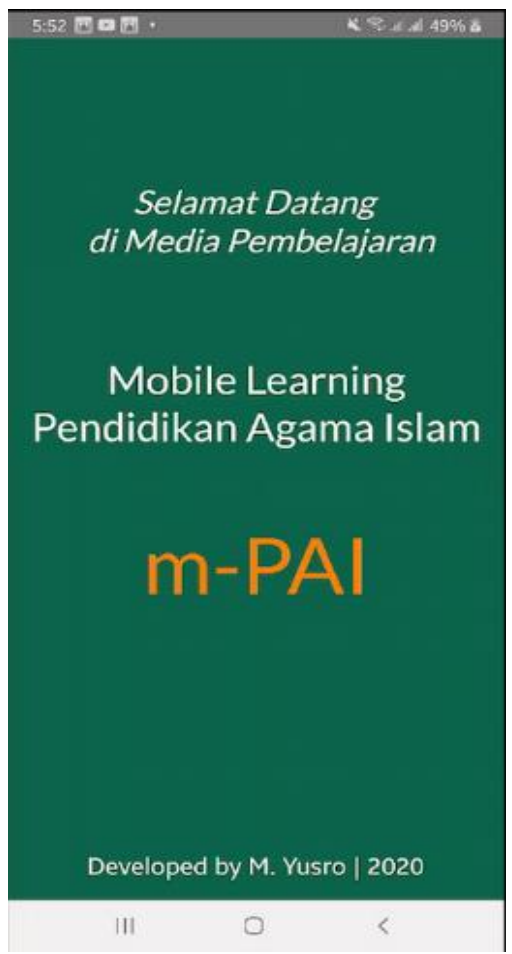

Figure 3. The initial appearance of m-PAI

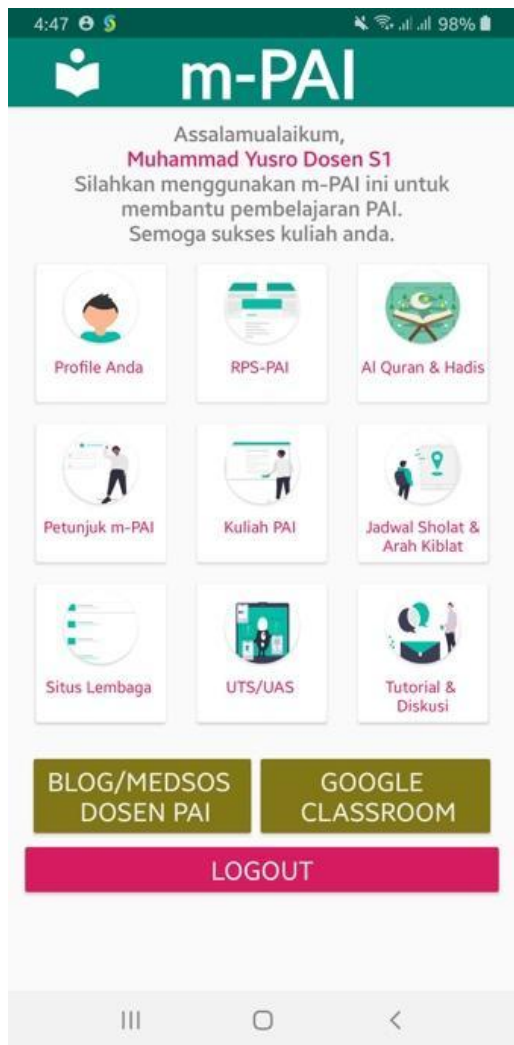

Figure 4. The main menu of m-PAI 
Some of the m-PAI content is connected to a web dashboard so that the content can be changed/edited by the lecturer who teaches the course. To take advantage of m-PAI, users can install the m-PAI application on an Android smartphone. Once installed, the user presses the m-PAI icon to start the application, the application will open with the initial appearance, as presented in Figure 3, while the main menu of m-PAI for students and lecturers is shown in Figure 4.

Before m-PAI is used in actual learning in Islamic Religion courses at universities, it is necessary to assess the feasibility of using m-PAI through a validity test. The validity test was carried out by Islamic material experts and media experts. The material experts in this study consisted of 2 people, namely senior lecturers in the PAI course with doctorate degrees from Universitas Negeri Jakarta (UNJ) and Universitas Islam Jakarta (UIJ).

The results of the validity test by material experts showed that the m-PAI, which was developed from the learning aspect, obtained an average value of $86.61 \%$ and the substance aspect obtained an average value of $84.38 \%$, which means it is valid and very feasible to use.

The validation test by media experts consists of 23 criteria. Media experts in this study consisted of 2 (two) experts; Professors in Computer Engineering from the Universitas Indonesia (UI) and Doctors in Educational Technology from the Universitas Negeri Jakarta (UNJ). The results of the validity test by media experts showed that the m-PAI developed from the general aspect obtained a mean score of $77.08 \%$, the software engineering aspect obtained a mean score of $84.03 \%$, and the visual communication aspect obtained a mean score of $81.82, \%$ which means valid and very feasible to use. Based on the results of the validation test by material experts and media experts, several improvements were made to the appearance and content of the m-PAI application. After the implementation phase, m-PAI was ready for use by users, namely lecturers and students.

The evaluation stage is carried out to assess the extent to which the usability of using m-PAI is in the hands of the user. Therefore, m-PAI was tested to be used by 5 (five) PAI lecturers and 15 (fifteen) students and then assessed the eligibility of m-PAI. The results of the lecturers' assessment of the use of m-PAI were $90.26 \%$, and the results of student assessments of the use of m-PAI were $84.28 \%$, so it can be concluded that $\mathrm{m}-\mathrm{PAI}$ is very suitable to be used as a learning medium mobile for PAI courses for students and lecturers.

The results of this study are in line with research on the development of Android-based learning media for PAI subjects for class XI at SMA Negeri 2 Malang (2016). The results showed that it is suitable for use from material experts of $73.5 \%$ and media experts of $86.6 \%$, and attractive to student users [12]. Other research on the development of PAI learning media using an android application with material for handling bodies for Class XI students at Muhammadiyah Vocational High School at Somagede (2019) obtained results from the feasibility level of material experts of $78 \%$ and media experts of $92 \%$ which are categorized as feasible and very feasible as well as for implementers PAI learning is $83 \%$ which is categorized as feasible [13].

Unlike the features of mobile learning in the playstore and similar research, which is only limited to material, video tutorials, or quizzes, the m-PAI produced from this study is designed comprehensively from the Semester Learning Plans (RPS) for undergraduate and diploma levels which consists of 14 materials. These 14 materials are translated into 14 modules at each level, equipped with a summary of the material in the form of a power-point (PPT/PDF). For deepening of each material, m-PAI provides features of exercises, assignments, mid-semester exams, and finalsemester exams. Students can also communicate with lecturers through the discussion forum (WA Group) feature. Video tutorials are also additional content on the m-PAI application. In building Islamic character in students, m-PAI is also equipped with features of prayer schedules, Qibla direction, digital Qur'an, and is connected to important sites such as Islamic organization sites.

Another thing that makes m-PAI different from similar applications is that this application is not static, meaning that the material contained in the m-PAI application can be changed (updated) by the lecturer (admin). The m-PAI application is connected to a webbased dashboard system, which makes this application more dynamic because the content can change at any time as needed. In the web dashboard, lecturers or PAI lecturer teams can update RPS content, teaching materials used, presentation of PPT/PDF, learning videos relevant to teaching materials, training and assignment materials, also mid and final exam materials.

\section{CONCLUSION}

This research has successfully developed mobile android-based learning media for Islamic religious education called m-PAI. The m-PAI application was developed using software Android Studio 4.0.1 so that this application can run on smartphones based on the Android operating system with the minimum specifications for the operating system (OS) Android Lollipop and a $3 \mathrm{G} / 4 \mathrm{G}$ internet connection. The m-PAI application is connected to the web dashboard as an editor space for updating existing content in the m-PAI application. 
The results of the validity test by material experts, media experts, and users (lecturers and students) show that the developed m-PAI is valid and feasible to use. Further development is recommended so that the m-PAI application can run on iOS (iPhone). The m-PAI application features can be improved by adding various learning animations and videos. The addition of more menus and features in the web dashboard is suggested so that used the content editor of the m-PAI application could more easily update the content.

\section{AUTHORS' CONTRIBUTIONS}

MY drafted the manuscript and designed the mobile application. AH conducted the respondent's interviews and provided data for tables 1 and 2. MS and RR validated the research instruments used. All authors reviewed and agreed on the final manuscript.

\section{ACKNOWLEDGMENTS}

This work was supported by the research grant from the Ministry of Education, Culture, Research, and Technology and The Research Institutions and Community Service (LPPM) Universitas Negeri Jakarta.

\section{REFERENCES}

[1] Y. Hanafi, “Transformasi Kurikulum Mata Kuliah Pendidikan Agama Islam di Perguruan Tinggi Umum: Dari Paradigma Normatif-Doktriner Menuju Paradigma Historis-Kontekstual," J. Pendidik. dan Pembelajaran, vol. 23, no. 1, 2017, pp. 027-037.

[2] N. Fathurrohman, "Konsep Kurikulum Mata Kuliah Pendidikan Agama Islam di Perguruan Tinggi Umum Berbasis KKNI (Studi Implementasi Pembelajaran MKWU PAI di UNSIKA)," Passon Islam. Stud., 2013, pp. 509-524.

[3] I. M. Ulum, "Desain Pendidikan Agama Islam," J. Pendidik. Agama Islam, vol. Vol. XIII, no. 1, 2016, pp. 53-64.

[4] U. Cahyana, M. Paristiowati, and S. Fauziyah, "Development of Android-Based Mobile learning media on Atomic Structure and Periodic Table," IOP Conf. Ser. Mater. Sci. Eng., vol. 434, no. 1, 2018, DOI: 10.1088/1757-899X/434/1/012095.

[5] J. M. Romero-Rodríguez, I. Aznar-Díaz, F. J. Hinojo-Lucena, and M. P. Cáceres-Reche, "Models of good teaching practices for mobile learning in higher education," Palgrave Commun., vol. 6, no. 1, 2020, DOI: 10.1057/s41599-0200468-6.

[6] N. Ibrahim and I. Ishartiwi, "Pengembangan
Media Pembelajaran Mobile Learning Berbasis Android Mata Pelajaran IPA untuk Siswa SMP,' Refleks. Edukatika J. Ilm. Kependidikan, vol. 8, no. 1, 2017, DOI: 10.24176/re.v8i1.1792.

[7] M. Yusro, "Mobile Learning Application for Personal Computer Assembly Techniques as Learning Media in Vocational,” ADRI Int. J. Inf. Technol., vol. 1, 2017, pp. 9-13.

[8] Sugiyono, Metode Penelitian: Kuantitatif, Kualitatif dan R\&D, 23rd ed. Bandung: Alfabeta, 2016.

[9] R. M. Branch and T. A. Dousay, "Survey of instructional design models," 2015.

[10] S. M. Alnajdi, “The Effectiveness of Designing and Using a Practical Interactive Lesson based on ADDIE Model to Enhance Students' Learning Performances in University of Tabuk," J. Educ. Learn., vol. 7, no. 6, 2018, p. 212. DOI: 10.5539/jel.v7n6p212.

[11] E. Widyastuti and Susiana, "Using the ADDIE model to develop learning material for actuarial mathematics," J. Phys. Conf. Ser., vol. 1188, no. 1, 2019, DOI: 10.1088/1742-6596/1188/1/012052.

[12] A. R. Sibilana, "Pengembangan Media Pembelajaran Berbasis Android Mata Pelajaran Pendidikan Agama Islam untuk kelas XI di SMA Negeri 2 Malang," Universitas Islam Negeri Maulana Malik Ibrahim Malang, 2016.

[13] R. H. Hanafi, "Desain Media Pembelajaran Pendidikan Agama Islam Berbasis Aplikasi Android Materi Pengurusan Jenazah Untuk Siswa Kelas XI Sekolah Menengah Kejuruan," Atthulab, vol. 4, no. 1, 2019, pp. 99-104. 